Conflict Prevention and 


\section{Conflict Prevention and \\ Decentralized Governance \\ Some remarks about the state of the art in theory and practice}

Rafael Grasa

International Catalan Institute for Peace

Universitat Autònoma de Barcelona

Arnau Gutiérrez Camps

Internacional Relations Directorate, Province of Barcelona

Universitat Autònoma de Barcelona

Translation by Catherine Charrett, International Catalan Institute for Peace

Paper presented at the Barcelona Forum on Decentralizated Governance and Conflict Prevention, July 2009. The Forum was organized by the ICIP, the Generalitat de Catalunya and the UN System Staff College. 
2nd edition: march 2010

(C) Institut Català Internacional per la Pau

Gran Via, 658, baix. 08010 Barcelona

T. 935544270 | F. 935544280

recerca.icip@gencat.cat |www.icip.cat

\section{Editors}

Javier Alcalde and Rafael Grasa

\section{Editorial Board}

Pablo Aguiar, Alfons Barceló, Catherine Charrett, Gema Collantes, Abel Escribà, Vicenç Fisas, Tica Font, Antoni Pigrau, Xavier Pons, Alejandro Pozo, Mònica Sabata, Antoni Segura i Josep Maria Terricabras

\section{Graffic Designer}

Cla-se

\section{Typesetting / Printing}

Ātona, S. L. / Gama, S. L.

\section{ISSN}

2013.5793 (online edition)

2013.5785 (paper edition)

DL

B-4.337-2010

\section{All rights reserved}




\section{ABSTRACT (ENG)}

Is there a link between decentralized governance and conflict prevention? This article tries to answer the question by presenting the state of the art of the intersection of both concepts. Provided that social conflict is inevitable and given the appearance of new threats and types of violence, as well as new demands for security based on people (human security), our societies should focus on promoting peaceful changes. Through an extensive analysis of the existing literature and the study of several cases, this paper suggests that decentralized governance can contribute to these efforts by transforming conflicts, bringing about power-sharing and inclusion incentives of minority groups. Albeit the complexity of assessing its impact on conflict prevention, it can be contended that decentralized governance might have very positive effects on the reduction of causes that bring about conflicts due to its ability to foster the creation of war/violence preventors. More specifically, this paper argues that decentralization can have a positive impact on the so-called triggers and accelerators (short- and medium-term causes).

Keywords: violent conflict prevention, war causes, decentralised governance, decentralisation, violence preventors, peace building

\section{ABSTRACT (CAT)}

Existeix alguna relació entre governabilitat descentralitzada i prevenció de conflictes? El present article intenta respondre a aquesta pregunta presentant la situació actual de la intersecció entre ambdós conceptes. Partint del fet que el conflicte social és inevitable, així com de l'existència de noves amenaces i conflictes i de noves demandes de seguretat basades en les persones (seguretat humana), les nostres societats han d'intentar que els canvis siguin pacífics. A través d'un exhaustiu anàlisis de la bibliografia existent i de l'estudi de diversos casos, aquest article sosté que la governabilitat descentralitzada pot contribuir a aquests esforços transformant conflictes, fomentant el repartiment de poder i augmentant els incentius d'inclusió de grups minoritaris. Tot i la dificultat de mesurar el seu impacte sobre la prevenció de conflictes, s' argumenta que la governabilitat descentralitzada pot tenir un impacte molt positiu en la reducció de les causes que produeixen conflictes gràcies a la seva habilitat per crear war/violence preventors. Més concretament, en aquest article se suggereix que la governabilitat descentralitzada pot influir positivament sobre les causes a curt i mitjà termini.

Paraules clau: prevenció de conflictes violents; causes de les guerres; governança descentralitzada; descentralització; preventors de la violència; construcció de pau 


\section{ABSTRACT (ESP)}

¿Existe alguna relación entre gobernabilidad descentralizada y prevención de conflictos? El presente artículo intenta responder a esta pregunta presentando la situación actual de la intersección de ambos conceptos. Partiendo del hecho que el conflicto social es inevitable, así como de la existencia de nuevas amenazas y conflictos y de nuevas demandas de seguridad basadas en las personas (seguridad humana), nuestras sociedades deben intentar que los cambios sean pacíficos. A través de un exhaustivo análisis de la bibliografía existente y del estudio de varios casos, este artículo sugiere que la gobernabilidad descentralizada puede contribuir a dichos esfuerzos transformando conflictos, fomentando el reparto de poder y aumentando los incentivos de inclusión de grupos minoritarios. A pesar de la dificultad de medir su impacto en la prevención de conflictos, se argumenta que la gobernabilidad descentralizada puede tener un impacto muy positivo en la reducción de las causas que producen conflictos gracias a su habilidad de crear war/violence preventors. Más concretamente, este artículo sugiere que la gobernabilidad descentralizada puede influir positivamente sobre las causas a corto y medio plazo.

Palabras clave: prevención de conflictos violentos, causas de las guerras, gobernanza descentralizada, descentralización, preventores de la violencia, construcción de paz 
Paper presented at the Barcelona Forum on Decentralizated Governance and Conflict Prevention, July 2009.

\section{INITIAL ASSUMPTIONS AND OBJECTIVES}

This draft of a working paper summarizes parts of an ongoing investigation into decentralized governance and the prevention of violent conflicts. This paper, which also acts in preparation for a special observatory to be developed by the International Catalan Institute for Peace on this topic, puts forward two tasks:

- An extensive analysis of the existing literature dedicated to conflict prevention and in particular the capacity of decentralized governance to provide inclusive incentives and reduce (or eliminate) the risk of violence in one or more phases of conflict. Specific case studies of decentralized governance emerging from process of peacebuilding and peace agreements, as well as emerging from development processes generated through international initiatives for development cooperation will be awarded specific attention.

- The conceptualization and specification of the terms conflict prevention, decentralized governance and other such related concepts will be developed in order to devise operational definitions.

Both of the aforementioned objectives are addressed in part in this paper, which was prepared for the Barcelona Forum on Decentralized Governance and Conflict Prevention. The concept paper for the Conference states the following:

\section{BOX 1: BARCELONA FORUM, CONCEPT PAPER, 2009}

Decentralized and local governance has increasingly been regarded as an instrument for transforming conflicts and building peace. In this concept paper, decentralized governance is intended in its most comprehensive sense, which includes not only the relocation of competences within central institutions (deconcentration) but also the transfer of some specific tasks to the private sector (deregulation; private-public partnership) and to non-central governmental institutions (devolution).

In spite of this high potential, little attention has, however, been devoted to the role that decentralized governance and non central authorities (local and regional, in the EU language) may play in either preventing or exacerbating conflicts. Case studies analyses present mixed results. In a number of contexts character- 
ized by political volatility, actions aimed at increasing local governance capacity have had a positive impact on the process of national reconciliation by curtailing possible threats to security (India, Macedonia, Aceh). In theoretically similar circumstances, devolution efforts have failed to prevent conflict and, in some extreme cases, they have even perhaps, intensified the level of confrontation (Bolivia, Southern Philippines).

Following the concept paper, we have organized our research from three initial assumptions:

- Various approaches in peace research and conflict resolution, development studies and human security believe that decentralization and local governance can be used as tools in the transformation of conflicts and the construction of lasting peace, particularly when decentralization is understood as a genuine devolution of power to non-central governmental institutions. This explains why, for more than a decade, international organizations and the academic world have insisted on the benefits of decentralized governance.

- Within the research conducted on decentralized governance less attention has been paid to the specific link between peacebuilding and decentralization. The role that decentralized governance retains as a tool to defuse violent situations or manage tense environments before they escalate into a significant armed clashes such that decentralization acts as a preventor of violent behavior has been less investigated. It is precisely this aspect, the possible causal relationship between decentralized governance and the prevention or resolution of conflict, which deserves further analysis. Particularly, two types of cases, which have become more prominent in the last twenty years, need to be assessed: those resulting from transitions in the Eastern Europe, as well as those emerging from changes taking place in the Global South as a result of peace accords or development process occurring with the participation of the international community.

- A priori, and due to the available data, one is forced to start from an ambivalent hypothesis; the case studies of recent years present contradictory results, displaying both negative and positive impacts at the short, medium and long term. Accordingly, this paper aims to primarily, present the state of the art of the theory and practical application of decentralized governance and conflict prevention. It will also reflect on the successes and failures of decentralization in relation to conflict prevention. Secondarily, this paper wants to provide a framework of operational concepts and definitions which is imperative to the analysis of this issue. Finally, it intends to draw a series of theoretical conclusions and provide recommendations for future research areas. 
In summary, the most basic question which must be both theoretically and practically addressed is how, in a post-Cold War environment of new armed conflicts, the relationship between "conflict prevention" and "decentralized governance" is defined. The interaction is examined through three frames of analysis, which can be taken individually and/ or in tandem. The first framework is from a conflict resolution and peace research perspective. The second explores the relationship through an institutional design frame, focusing on elements such as democratization and decentralization. Finally, strategies of power-sharing and inclusion incentives in peace negotiations and agreements are employed as an analytical framework. The following box illustrates the three approaches to investigating the link between decentralized governance and conflict resolution.

\section{BOX 2: ANALYTICAL FRAMEWORK AND ASSUMPTIONS ON THE RELATIONSHIP BETWEEN DECENTRALIZED GOVERNANCE AND CONFLICT TRANSFORMATION}

1. "Conflict Resolution" and "Peace Research" is the first framework for analysis which will provide the bases for the investigation into the relationship between the two components. The central thesis of peace research is that any society can cope, given the appropriate instruments (so-called war preventors), with prospective conflict, however complex they may be through peaceful change. . Or at least when violent change finds itself in conflict situations with peaceful change the net result will favor a peaceful resolution. This approach entails a certain way of understanding conflict prevention and peacebuilding which takes the latter as encompassing the first. This approach to conflict prevention, therefore, privileges two types of action in war- and conflict-torn societies in order to manage tense environments and bring about peace. The first response focuses on institutional choice (democratization and decentralization). The second strategy is one of powersharing, also understood as "peace governance", the two additional analytical frames are explained below.

2. Institutional design and power-sharing are argued here to be two pillars of peaceful change in developing societies or in societies that are emerging from an armed conflict or trying to prevent such a fate. These foundations act as the base for the second analytical framework: the institutional design process, involving democratization in post-conflict societies or those societies with grave issues of inequality and exclusion. In such cases institutional design can be applied to generate forms of democratic decentralization in order to promote progressive peaceful change. This tactic will include important forms of devolution of power to decentralized authorities, as well as crucial elements of social inclusion that will help afflicted individuals to lay down their arms. 
3. The third analytical framework emerges, within contexts of peacemaking and peacebuilding (political negotiations to end conflicts, in other words peace processes), from different power-sharing mechanisms and strategies which accept a broad understanding of the concept. In sum, governance incentives offered to induce armed groups to negotiate and implement peace agreements often include incentives such as resource-sharing, inclusion in security structures and several forms of territorial autonomy (Harzell and Hoddie 2007).

In conclusion and as a result of the fact that decentralized governance can potentially reduce the risk of conflict arising or that it can help resolve conflicts, promoting decentralization and self-governance have become key elements of political and administrative reform in many countries in the last twenty years.

Following the objectives listed above, the structure of this paper will consist of:

\section{BOX 3: OUTLINE}

1. Initial Assumptions and objectives

2. The Context: from international conflicts to human security

3. The Analytical Framework: peace research and war and violence preventors

4. The Conceptual Framework and Operational Definitions: conflict prevention and decentralized governance

5. The state of the art: two points of view on the theory practice

5.1. The Macro Point of View: democratization, power-sharing and development

5.2. The Meso Point of View: pros and cons of decentralized governance as conflict prevention tool

6. Conclusions and Further Research

7. Bibliography 


\section{THE CONTEXT: FROM \\ INTERNATIONAL CONFLICTS \\ TO HUMAN SECURITY}

To initiate our discussion, we feel it is important to draw attention to several items in international relations which currently shape the global environment and, consequently, our evaluation of the topic at hand. The end of the Cold War has given way to several key changes, which have been further impacted by the evolution of globalization, such as the transformation of the concept of international security, the emergence of new armed conflicts, and the deepening of economic inequality and social exclusion. The global community has also been reformed through an international convergence of agendas concerning peace, security and development. There has been a shift in the main reference point, whereby there is a greater focus on individuals and communities, which is enacted through concepts such as human security and the "responsibility to protect."

Evidence of such global phenomena is witnessed through the observation of conflict trends in recent years. There have been a relatively small number of major armed conflicts (about thirty a year); however, by the fact that the majority of these conflicts are internal conflicts, there exists a constant risk of violence and conflict reemerging. Many of these intern conflicts are fought over access to state power and claims to autonomy, as well as being defined by secession movements. Moreover, some of these conflicts become internationalized.

Secondly, we are reminded that security is understood as multidimensional societal, political, economic, environmental and military processes, which involve new risks and threats to newly defined groups. Tools which observe such processes of securitization and politicization are now also required in order to understand such new types of conflict. Thirdly, we would like to draw attention to the importance of the growing convergence of agendas and the international cooperation on ideas of peace, security and development. This convergence often revolves around the notions of "human security" and "human development" (a process, according to Amartya Sen that improves the wellbeing of the individual, their life options and enhances their capacity to make a better life for him/herself).

Regarding the socioeconomic dimension, what matters most in a contemporary global setting is the growth of economic inequality and social exclusion. The Global South continues to face the deterioration of structural conditions, affecting many groups and individuals. This damaging fact exacerbates the risk of violence and potentially leads to the rise of asymmetric conflicts. Additionally, the process of urbanization aggravates issues of disparity, potentially leading to further grievances. 
In 2008, for the first time in history, the majority of the world's population lived in cities. This phenomenon will continue to be accentuated, and by 2015 it is expected that $79 \%$ of the European population will live in cities, $80 \%$ of Latin America, $81 \%$ of the American population, and $47 \%$ of the Asian and African populations. These social transformations will most probably impact and create further problems of social cohesion and generate new economic challenges. This new reality will in turn effect the management of conflicts arising from economic inequality.

The various factors mentioned above, currently defining global relations, have once again drawn our attention to two major features of contemporary conflict management, namely conflict prevention and peacebuilding. These two elements, which carry a lot of importance each in their own right, are also very much intertwined: on the one hand, conflict prevention aims at avoiding wars and/or preventing the recurrence of wars once they have occurred; on the other hand, peacebuilding does not seek to eliminate conflict (which is impossible), rather it intends to develop effective mechanisms by which a polity can resolve its rival grievances, claims and competitions in a peaceful manner.

In other words, we understand both Conflict Prevention and Peacebuilding as processes of profound change and structural transformations (thus focusing on the root causes of violent behavior), which is what the European Union has calls "structural stability." This refers to the internalization of mechanisms for peaceful change allowing for the emergence of suitable institutions which will be able to meet basic needs and respect human rights, as we shall later observe. The creation, enhancement or strengthening of legitimate and reliable mechanisms to resolve conflicts without violence, typically involves creating spaces or arenas for political and institutional processes. The following box summarizes the definition and history of peacebuilding.

\section{BOX 4: ORIGINS AND DEFINITION OF PEACEBUILDING}

The term 'peacebuilding' came into widespread use after 1992 when Boutros Boutros-Ghali, then United Nations Secretary-General, announced his Agenda for Peace (Boutros-Ghali, 1992). Since then, 'peacebuilding' has become a broadly used but often ill-defined term connoting activities that go beyond crisis intervention such as longer-term development, and building of governance structures and institutions. It includes building the capacity of non-governmental organizations (including religious institutions) for peacemaking and peacebuilding. The emphasis of the United Nations has been on structural transformation, with a primary focus on institutional reform.

Peacebuilding involves a full range of approaches, processes, and stages needed for transformation toward more sustainable, peaceful relationships and govern- 
ance modes and structures. Peacebuilding includes building legal and human rights institutions as well as fair and effective governance and dispute resolution processes and systems. To be effective, peacebuilding activities requires careful and participatory planning, coordination among various efforts, and sustained commitments by both local and donor partners. To summarize a construction metaphor used by Lederach, peacebuilding involves a long-term commitment to a process that includes investment, gathering of resources and materials, architecture and planning, coordination of resources and labour, laying solid foundations, construction of walls and roofs, finish work and ongoing maintenance. Lederach also emphasizes that peacebuilding centrally involves the transformation of relationships. "Sustainable reconciliation" requires both structural and relational transformations (Lederach, 1997).

Precisely at this point is where we find an overall trend towards decentralization in countries both of the North and the South. The causal factors of such a global phenomena appear to be due to the impact of one or more of the following (Sharma, 2005): a) the processes of democratization: the movement began in the seventies and during the eighties and nineties it was followed by a strong wave of decentralization processes; b) economic development: the erosion of the power of the central government as result of globalization has given further value to territory and has, therefore, endowed subnational governments, cities and regions with new and crucial roles and functions in governance (simultaneously, there has been an increase in economic drivers and an interest in innovation); and c) political heterogeneity and conflicting demands: many experts express that the most important and significant factors are the demand for autonomy and the request for powersharing arrangements, which act as the root cause for many decentralization processes.

Exogenous pressure has also been partially responsible for the increasing global trend in decentralization. Box 5 shows us how international organizations, particularly in the context of cooperation for development, have notoriously promoted decentralization.

\section{BOX 5: ROLE OF INTERNATIONAL ORGANIZATIONS IN THE PROMOTION OF DECENTRALIZATION}

The support and pressure of international organizations for decentralized governance can in part explain the extent of this global, political trend. Many developing countries have opted to embrace policies that promote decentralized governance due to the direction and/ or suggestion of institutions such as the European Commission or the World Bank. Many international donors also 
favour decentralization movements and they have proceeded to include such reformations as a condition for obtaining funds. The European Commission, above the promotion of decentralization among its members and beyond upholding the principle of subsidiarity, also devotes a large amount of funds to promote processes of decentralization and local governance. An example of this support is the EU-Africa Lisbon Summit Declaration (December 2007), which in section II declares the following "To facilitate and promote a broad-based and peoplecentered partnership wideranging, Africa and the EU will empower non-state actors and create conditions to enable them to play an active role in development, democracy building, conflict prevention and post-conflict reconstruction processes." (European Commission, 2007)

The World Bank presents a distinct approach. For the sake of effectiveness it demands that receiver countries reduce the weight of the central state. It also requires that they expand the private sector, and look to strengthening subnational government. To facilitate such progress the World Bank has developed the "Decentralization and Subnational Thematic Group", which aims "to share information and deeper knowledge among a wide range of practitioners-macro, sectorial, urban, and rural-to bring about a more informed, consistent and comprehensive approach to decentralization and development in our Subnational country programs. The Thematic Group seeks to share knowledge and Deep on intergovernmental relations, regional development and poverty reduction, and central and local governance to enhance the effectiveness of multi-tier governments." (World Bank's Poverty Reduction and Economic Management Network website)

In conclusion, the context described above shows that, while there is an increase in domestic violent conflicts, is not a coincidence that a new wave of decentralization is underway. Many countries, since the year 2000 have been implementing, or at least discussing, reforms towards decentralization. This trend led Manor to the conclusion that "decentralization has quietly become a fashion of our time. It is being considered or attempted in an astonishing diversity of developing, developer and transitional countries, by solvent and insolvent regimes, by democracies (both mature and emergent) and autocracies, by regimes making the transition to democracy and by other seeking to avoid that transition, by regimes which varied colonial inheritance and which none. It is being attempted where civil society is strong, a where is weak" (Manor, 1999: 12).

We will now focus on the conceptual and analytical framework part of this paper, which deals specifically with grounded attempts to prevent violence and war, taking a particular look at cases where new conflicts, the so-called 'emerging conflicts', are arising. 


\section{RESEARCH AND WAR/VIOLENCE PREVENTORS}

The desire, both academic and political, to prevent wars has always been accompanied by the debate surrounding the causes of wars. Thus, the primary focus of this paper is how to achieve peaceful social and political change given the emergence of new causes for conflicts.

One of the responses to the challenges posed by the possible materialization of war was the birth of peace research in the fifties. The goal of peace researchers was to reform the International Relations field to find out the causes of war and conditions for peace. During the second half of the twentieth century, peace research has been significantly altered; Oliver Richmond has called it the "transformation of peace from the matrix of the liberal peace" (Richmond, 2008). Concretely, there has been a "hybridisation of the different discourses of peace and their associated actors that has lead to a contemporary understanding of liberal peace as constituted by different forms of governance and within the forces of globalization. This has come to be constituted in a peacebuilding consensus" (Richmond 2008: 83).

Within this working framework, the mainstream attempts to understand the causes of war and violence translated into a coordinated search for what would be the most suitable preventors of war. According to Miall "a cause of war is a factor that brings war about. In a similar way, a 'preventor' is a factor that tends to preserve peace, at least in the negative sense" (Miall 2007: 15), in the sense of the absence of a war. Therefore, a preventor implies a positive element, something to be achieved; it is not merely the absence of violence. The causes and preventors of war can be understood as a causal factor of bringing about an effect. Thus, a preventor has the capacity to bring about the non-ocurrence of a war.

However, can we analyze and discuss the causes and preventors of war and violence from a unitary starting point; either the single-cause or the single-preventor? The current study and practice of Peace Research -together with the analytical framework and data used for this paper- have shown that conflicts are always multifaceted: not a single war or armed conflict can be attributed solely to one causal factor, although it may be that during a particular phase of a conflict one causal factor might dominate. An important distinction should be made between distant causes (factors and items with some influence, albeit very indirectly) and direct causes. Moreover, it is necessary that we conceptually distinguish between several sorts of causes:

- Immediate (triggers) or underlying causes (which can be structural causes), given its relation with the outbreak of conflicts.

- Efficient (accelerators or triggers, which can be regarded as specific causes for a particular case) or permissive causes (external conditions, for example the inter- 
national system, which could be responsible for the outbreak of hostilities), given its degree of responsibility to the conflict.

- Necessary (which must be present for a conflict to be triggered, along with other causal factors) and sufficient causes (root causes which explain the basic reason for the outbreak of the war or violence).

When addressing causation, and taking into account the methodological guidelines which were just outlined, it is suggested that Peace Research and Conflict Resolution should distinguish between three types of causation:

- Structural causes, that is, necessary causes, such as relative deprivation or grave injustices prevalent in asymmetric conflicts, which serve as the basis and foundation for greed or grievance upon which a particular side or group can build a case. Without them there would be no conflict, but often these factors do not lead to violent behavior.

- Accelerators or intermediate causes (causes, facilitators, conductors), which allow for the exacerbation and the advancement of hostilities.

- Triggers or immediate causes (the drop that fills the cup), which explains the outbreak of violence after a phase of escalation and the presence of structural causes.

In other words, the causal factors for war are present at, at least three different levels, each needing to be analyzed separately: firstly, the background level or structural context needs to be observed; then, the middle level or factors present at close proximity (accelerators) and, finally, the immediate level (triggers).

If we apply this knowledge to the matter at hand, then the task of understanding the causes of war as well as the conditions which are required to avoid it (causes and preventors) becomes clear. The following conclusions can be drawn concerning the causes and preventors of war based on the aforementioned evaluation (Miall, 2007).

\section{BOX 6: CAUSES AND PREVENTORS OF WAR}

- Causes of war will normally only be effective when they operate together, in particular contexts (accelerators) and given particular conditions (trigger conditions).

- Similarly, preventors of war normally need to act in combination and often may depend on contingent conditions.

- Just as the causes, we can -we must- look for preventors at different levels: structural, proximate and immediate

- Causes and preventors, in short, are not exclusive categories. They co-exist. There are examples of societies with a long tradition of peaceful relations and peaceful change which, nevertheless, are now at war. 
Therefore, in accordance with what has been the standard practice for centuries and in congruence with mainstream thinking in peace research and conflict resolution studies, the task of achieving peaceful change is possible in any society if a combination of different types of violence preventors is applied. It is not mere wishful or utopian thinking to believe that war can be prevented. Rather, it has been demonstrated in recent history by the realities of societies which make up security communities for example (i.e. Scandinavia) as well as by those which have avoided war for long periods. This is shown by the fact that some sixty countries, for at least sixty years, have not gone to war with each other.

If we consider very long historical cycles (over the course of centuries), there is evidence that social change has always occurred through a combination of peaceful and violent change. Numerous macroanalytical, historical and sociological works (Charles Tilly, for example) show that the actor, who has most often resorted to violence is the state, particularly during processes of state formation, expansion and consolidation. Other studies and analyses, meso or micro in nature, have shown that the majority of societies have simultaneously experienced both peaceful and violent transformations. This point is very relevant to the subject because shows that the issue-areas which prompt violence also change themselves with social conditions (Luard,1986). There is therefore, a growing consensus which leads us to formulate the following argument: in most societies peaceful and violent change coexist and, provided that social conditions are altered, new sources of conflict emerge (or emerging conflicts could involve the reappearance of violence and past grievances).

However, even in such cases where the possibility of violent conflicts emerging is imminent, there are practices and instruments (preventors) which allow for the extension of the domain of peaceful change vis-à-vis violent change. For this result to be achieved, it is essential to know in which dimensions the preventors should occur, so that social processes of transformation and accommodation may take place peacefully.

As we already touched upon, modern-day armed conflicts in the post-Cold War era are mostly internal, domestic in nature, and are located primarily in the Global South, where recently or even over the last centuries violent change has dominated over peaceful change. To alter this fact, whereby the causes for this imbalance are modified in order to benefit peaceful change, three main areas or dimensions where preventors can be located and consolidated must be identified.

There are three elements which are essential to promote processes of peaceful social change, to the extent that institutions and relationships are agreed upon in order to manage inevitable social conflicts. The first is democratization and institutional design, which focus on the institutional policies and procedures for resource allocation and the resolution of potential disputes. The second crucial factor is development; this pays attention to structural changes, in seeking to reduce imbalances, improve the welfare of individuals, communities and social groups and seeks 
to reduce the maximum inequality and social exclusion possible. The final element is good governance, which includes various incentives for political inclusion and power sharing arrangements. These three areas remain consistent with the analytical framework outlined in the introduction, especially if we take into account that two of them, democratization and good governance fit into our institutional choice and 'peace as governance' as short- and mid-term approaches, and that the third, development relates to the long-term structural changes.

These elements, which could be understood in terms of causality, can be represented graphically following Miall. The long-term attempt to change the status quo and conflicts are difficult to manage at the national, state, international or global level because their policies do not have the capacity to exclude the risk of polarization and violence.

\section{BOX 7: RESULTS OF SOCIAL CHANGE}

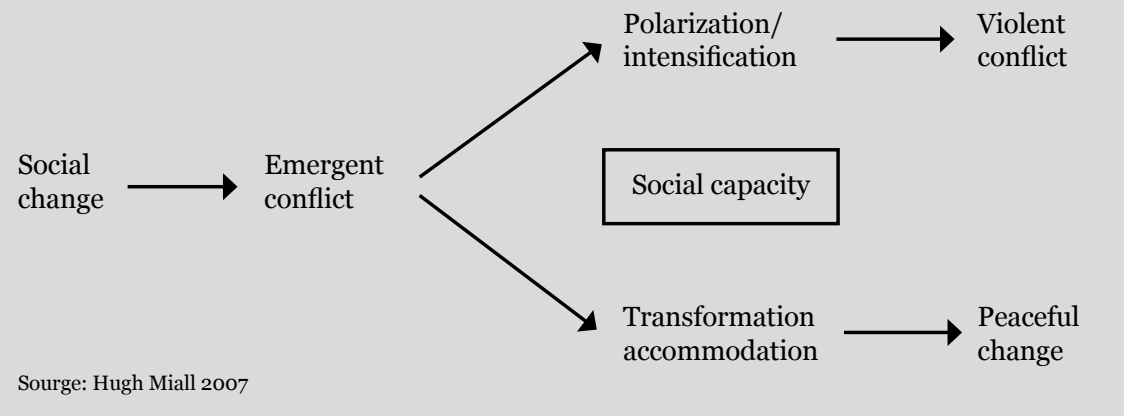

New forms of conflict generate new clashes, conflicts of interest, and incompatibilities, which may well evolve towards polarization and escalation, or conversely, towards negotiation and accommodation, thus transforming the conflict. This transformation can take the shape of peaceful or violent change. The path taken will depend on the external context (national, state, international or global level) which can promote either peaceful or violent change. The specific dynamic of the conflict, actors, incompatibilities and behaviors are also affected by the national or global environment in which the conflict is situated. The conflict, therefore, depends on the social capacity to manage, resolve and transform a volatile situation, as well as on the existence and the internalization of effective preventors. The capacity to improve the conflict environment -so that peace may be achieved or maintained-is also subject to the technical cooperation and the work of international organizations.

However, according to Miall's model, often these preventors operate in a more subtle and nuanced manner in the real word. They do not exist in a binary fashion; 
not least because, as Tilly (among others) has demonstrated, peaceful or violent change is largely dependent on the ability of key players to mobilize society towards violence or towards peace (Tilly, 2003). Therefore, it is necessary that we refine the analysis, as shown in the box.

\section{BOX 8: FOUR PATHS OF SOCIAL CHANGE}

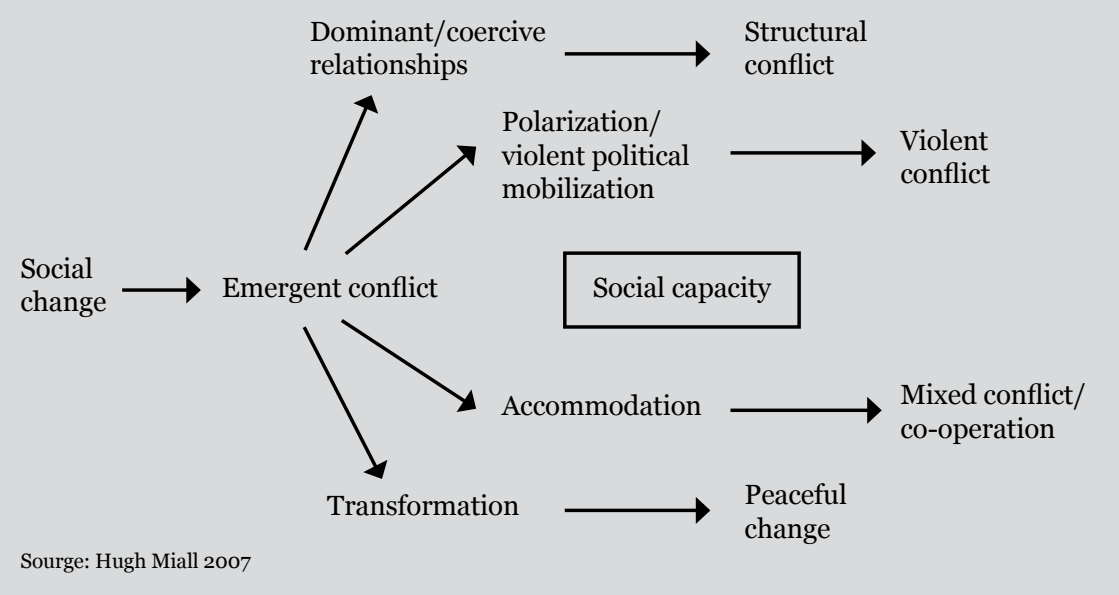

The figure offers a reformed model with four identified alternatives. When social changes occur (such as uneven development, a change in the status or the relative position of some ethnic groups, a transition of power, the introduction of a new production model or religious belief system), this can lead to an 'emerging conflict'. The first alternative, which is prevalent in many cases, simply leads to new or refurbished corrective relations or relations of domination and / or coercion. Therefore, in a structural conflict -where underlying, asymmetrical relation are prevalent- the hegemony or the use of coercive means ensure dominance is maintained. In other cases, demonstrated by the second path, the perception of conflicting interests may lead to the emergence of feelings of hostility and polarization, thus resulting in political mobilization and eventually violent conflict. On the contrary, and depicted by the third path, political mobilization may also lead to the organization of negotiations about the distribution of resources and power through the establishment of new political processes. Negotiations and efforts to implement new political arrangements, in a typical situation of mixed cooperation and conflict, however, do not necessarily exclude the possibility of a sudden outbreak of violence. Finally, there is a fourth alternative which can be selected, sometimes after the third alternative has been tried. The parties involved manage a deeper collaboration, genuine coopera- 
tion, and are able to transform the emerging conflict in a manner that is mutually beneficial to all parties. The likelihood of violence in the present and/ or the future is reduced. In this case one can speak of positive peace.

To conclude, the analytical framework can be summarized as follows:

- Research on peace and conflict resolution show that peaceful social change is possible, with no violence or very small amounts, even when conditions for emerging conflicts are present.

- In order for such a form of peace to be guaranteed, the success of conflict preventors in the three core areas, development -to avoid, as shown in Box 8, the persistence of structural inequalities-, democratization and institutional design, and lastly, good governance and mechanisms of power-sharing are all necessary. This is precisely where the link between conflict prevention and decentralized governance comes into the picture, as a way of fostering good governance and a better institutional setting. 


\section{THE CONCEPTUAL FRAMEWORK \\ AND OPERATIONAL DEFINITIONS: \\ CONFLICT PREVENTION AND \\ DECENTRALIZED GOVERNANCE}

We are now going to offer brief operational definitions in order to better understand the connection between both concepts.

Conflict prevention, the desire of preventing wars and violent behavior, is not new. However, it has changed shape since the end of Cold War. Forums on the issue of conflict prevention have multiplied the since the 9os, and the subject has been discussed and debated by politicians, secretary generals and by the heads of international organizations (directed in large part by the United Nations). Academics, members of major private foundations have also addressed this issue, as well as activists and members of civil society. In addition, specialized institutions have emerged, which have conducted very important studies on the subject matter, such as the Carnegie Commission on Preventing Deadly Conflict or through the work led by the International Crisis Group. For example, in the late nineties the United States Institute of Peace developed a Task Force on conflict prevention and the Council on Foreign Relations created a Center for Preventive Action, all dedicated to this issue. It can further be concluded that emphasis in this field has been placed on conflict prevention, more so than conflict management.

All of those listed above have significantly contributed to the current working definition of conflict prevention, although, without a doubt, one of the most impacting references (both political and academic) was described in former UN Secretary General, Boutros Boutros-Ghali's Agenda for Peace (Boutros-Ghali 1992). This report redefined the idea of preventive diplomacy created in 1960 by Dag Hammarskjöld and adapted it to the context of the post-Cold War. In the Agenda Boutros-Ghali refers to preventive diplomacy as a policy that was aimed at preventing conflicts from emerging, and also from escalating into violence. He discusses five specific measures; confidence-building, fact-finding missions, early-warning networks, preventive deployment and demilitarized zones. He also held that it was necessary to confront the underlying causes of violent conflicts through economic and social development.

Regarding 'conflict prevention', it exists a clear consensus on the definition, which is illustrated through Lund's classic definition. 


\section{BOX 9: DEFINITION OF CONFLICT PREVENTION}

Conflict prevention refers to " any structural or intercessory means to keep intrastate or interstate tensions and disputes from escalating into significant violence and the use of armed forces, to strengthen the capabilities of potential parties to violent for resolving such disputes peacefully and to progressively reduce the underlying problems that produce the issues and disputes” (Lund, 2002: 117)

Lund's definition of conflict prevention is consistent with Boutros-Ghali's ideas previously presented, through four main points: a) the type of intervention required may be temporarily limited or broad; b) it seeks to prevent the emergence of violence and intends to manage the escalation and or mitigation of violence; c) it seeks to enhance the capacities of the parties or stakeholders; and d) it emphasizes the importance of addressing, at some point, the underlying problems that generate disputes and problems.

In the'9os two major topics of scholarly debate on the matter emerged. The first, suggestion offered by some was to limit conflict prevention by focusing on nonescalatory, early stages of the conflict. In other words their proposal neglected the escalation and post-conflict stages of the outbreak of violence (Ackerman 2002, Leatherman 1999). Although it is believed here that prevention can reach the stage of hostility as well as the post-conflict, this article will apply a narrower definition of conflict prevention, which is pre-empting the eruption of violence. Thus, we are going to reduce our focus to the early stages of the conflict. The second topic of discussion focuses on the causation of conflict, namely the controversy about which objectives should be pursued or what should be the focus in the attempt to prevent conflict: "Light versus deep prevention" (Miall, 2007) or "operational versus structural prevention" (Carnegie Commission, 1997).

In sum, the overarching issue of debate is whether conflict prevention should focus on eliminating the root or structural causes for conflict, or concentrate on more short and medium term goals (what we called accelerators and triggers). In this study, we accept that deep-rooted causes of conflicts must be addressed, but it is argued that, in order to achieve peaceful social transformation, preventing the outbreak of violent, immediate causal factors must be awarded priority. Nonetheless, it remains vital to incorporate a peacebuilding approach, characterized by the transformation of the underlying, structural causes. In this approach, which remains consistent with the one developed above, the core areas of conflict prevention are institutional design and governance, leaving the deeper, long-term issues for development to tackle.

Decentralization, as a concept, is more complex to define and, specifically, in its particular form of decentralized governance. But before turning to the field of ter- 
minology, it should be remembered that in this paper it is assumed that decentralization is a mechanism or procedure, a tool to share power and divide responsibilities with the objective of improving the living conditions of citizens. If such political distribution functions then decentralization can be expected to prevent the emergence of violent conflict and / or minimize the risks of non-peaceful change. We return to this relationship later.

In other words, to talk of decentralization, despite its many nuances, is to talk about political power and government levels and how these are constructed. For example the reorganization of the state through the transfer or devolution of responsibilities to subnational levels of government is a topic of decentralization. It remains a topic of institutional choice and design, systems of democracy and types of governance

\section{BOX 10: DEFINITION OF DECENTRALIZATION}

"Decentralization is not about the downsizing or dismantling of central government; rather, it calls for mutually supportive democratic central and local governance. [...] Decentralization is any act in which a central government formally cedes powers to actors and institutions at lower levels in a political-administrative and territorial hierarchy" (Ribot, 2002).

"Decentralisation refers to the restructuring or reorganization of authority so that there is a system of co-responsibility between institutions of governance at the central, regional and local levels according to the principle of subsidiarity, thus increasing the overall quality and effectiveness of the system of governance, while increasing the authority and capacities of sub-national levels" (UNDP, 1999)

Naturally, the process of strengthening and improving sub-governmental systems consists of the devolution of political, administrative and financial power away from the central government. Without being exhaustive, it is worth briefly reviewing the different types and sizes of decentralization processes.

Political decentralization refers to alterations to the structure of government through the devolution of power and authority to lower levels of government. It is also associated with powersharing through the recognition of federal principles, autonomous regions and the like. Political decentralization also includes procedures to increase the participation of citizens and of civil society in their selection of governmental representatives and in political decision-making (Cheema and Rondinelli, 2007). The objective is that lower levels of government become accountable to the public. 
Administrative decentralization involves the devolution of bureaucratic structures away from the central government to lower levels of power, without removing their accountability to the central government. The effective decentralization of the governmental administrative body requires that local and regional governments have the ability to establish ordinances and regulation or bylaws, which they consider to be appropriate within their jurisdictions. Furthermore, it necessitates that there is no central control on matters of internal functioning (such as hiring and firing staff) (Shah and Thompson, 2004).

Finally, we come to fiscal decentralization, which entails the agreed upon means by which revenue is shared between levels of government, including the delegation of tax collection and public expenditure.

At this point, we would like to include a note on the more general debate about decentralization: how to carry out decentralization and what kind of power transfer to non-central governmental institutions should take place first. Following Sharma, box 11 contains this two-pronged discussion (Sharma, 2008).

\section{BOX 11: HOW TO DECENTRALIZE?}

One of the debates in this area is related to the order and the speed at which it acts of decentralization should be implemented. There exists a major issue regarding the implementation of decentralization processes refers to where it should start. Some experts believe it is necessary to initiate the process in the political sphere because without the institutionalized capacity for action and the political know-how fiscal decentralization, for example, is meaningless (Boex, 2001). At the other extreme there are the proponents who such suggest that initiating the process with fiscal decentralization, as they believe that political decentralization without the proper resources is not possible (Blanchard and Schleifer, 2000). Secondly, we encounter the discussion on the manner of how to carry out decentralization, should the process be gradual or sudden. Some experts advocate the need to implement changes in a phased manner (a slow and incremental deployment of decentralization policies); this thinking is based on the importance of the learning curve of the actors involved in and impacted by such changes. This approach would allow alterations and adjustments during the process of decentralization (Prud'homme, 2001). Conversely, there are those who favour a big bang approach to ensure that the process is not stalled because of the establishment of alliances between actors who opposed decentralization due to the perception that it may impact them negatively (Sato, 2002). 
Regarding the different types of powersharing, the literature tends to distinguish between three basic sorts of powersharing or, more specifically, three levels of depth. The first, and lowest in intensity, of these types is deconcentration, which is the territorial dispersion of central power through the shift in the responsibility for implementing governmental decisions away from the central government. With deconcentration, this small transfer of power does not usually go to an elected representative presiding over the territory, but to an appointed official, meaning that the central government maintains control over resources and prioritized tasks. Secondly, there is delegation, which refers to transfer capacities to non-central governmental institutions in issues/areas where these levels already have competences, but being responsible to central governments. Lastly, we find devolution, which is a full transfer of responsibilities to lower levels of government, thus allowing them to freely exercise the authority and carry out their functions (which should be legally stipulated), based on the confidence that the central government places in the non-central governments (Siegle and O'Mahony, 2007).

These forms or levels of decentralization occur in many areas of public policy, and the given result of the decentralization process is different with each type. Given the multiplicity of players, fields and formulas, it is not possible to speak of a single model or a universal recipe for decentralization. Consequently, another point of debate and reflection is how to attain a suitable balance. The result of the decentralization process depends on many factors. But the question remains, how to find a lasting balance? It is impossible to find an equilibrium given the fact that societies change, evolve and adapt to new realities.

On the other hand, it is worth remembering that the processes of decentralization cannot rest solely on the structures of the state. Participation is indispensable and a healthy balance between the public and the private sector is also required. In short, to apply a political-philosophical metaphor, a functioning decentralized system demands an equilibrium between the prince, the merchant and the citizen.

In other words, one can speak of the existence of a creative tension that moves at the same speed as society and the actors in it. Accordingly, the degree of decentralization and the size of the state will depend on the relationship between economies of scale -which favours the existence of large, centralized states- and the heterogeneity of the population and its needs -which tends to favour small states and further decentralization (Alesina and Spolare, 2003).

This is where decentralized governance comes into play. Remember that until the early eighties, it was generally regarded that state and government were quasisynonymous or interchangeable, but in the late eighties and early nineties, governance began to symbolize something other than the government. It has been said that the concept has evolved along three stages. In the first phase, the focus was placed on deconcentrating hierarchical governmental structures and bureaucracies. In the second stage, transpiring in the mid-eighties, the concept was expanded to include 
political power sharing, democratization and market liberalization, implying that the decision makers were already situated within the private sector. In the latest stage, since the nineties, decentralization became defined as wider public participation through the organization of civil society "(Cheema and Rondinelli, 2007).

The concept of governance was, therefore, expanded to include not only governmental bodies but also other social institutions, particularly the lucrative private sector and civil society. Evidently, hand in hand with the expansion of the meaning of governance and the inclusion of new players, conceptual changes also occurred at the regarding the understanding of decentralization; it adopted new forms and meanings. Generally the consolidation of these changes refers to decentralized governance.

For operational purposes therefore, decentralized governance, in this text will be understood as mechanisms and efforts taking place in all three dimensions of decentralization (political, financial and administrative) with the objective of devolution or powersharing between different governmental institutions, including actors in the private and public sectors. 


\section{THE STATE OF THE ART: TWO \\ POINTS OF VIEW ON THE THEORY \\ AND PRACTICE}

In our investigation we refer to a series of books and articles that offer different perspectives and approaches on to the conceptual and methodological aspects of the relationship between conflict prevention, decentralization or decentralized governance. These sources also offer assessments of a variety of case studies, evaluating the performance and outcomes of concrete experiences. We will review in this section the results of these sources, particularly the more meaningful findings. We have conducted our evaluation of the literature on decentralization and conflict prevention in two manners, specifically, macro and meso approaches:

- The first approach is a macro view of the relationship between the two phenomena. From the notion of peace and the proposals of peace research, we focus specifically on three major areas: democratic design and peace governance; power- sharing; and, finally, the pursuit of human development, as was outlined in the first sections of this paper. Here, therefore, we offer a brief analysis of the studies and the analysis that are only indirectly concerned with the relationship between conflict prevention and decentralized governance.

- The second approach focuses on the meso elements of the connection. Applying the same assumptions and principles about the notion of peace and the proposals of peace research, the meso perspective focuses on the pros and cons discussed in the literature directly oriented to the study of decentralization and its particular impact on conflict prevention.

In both cases, the analytical framework is the same: to deconstruct and reconstruct the arguments made in order to observe the possible positive and negative impacts in terms of causes and preventors. They both focus on the underlying structural causes, intermediate causes, as well as triggers or accelerators of conflict.

\subsection{THE MACRO POINT OF VIEW: DEMOCRATIZATION, POWER-SHARING AND DEVELOPMENT}

We will focus on three macro perspectives of cases whereby countries find themselves in transition, emerging from armed conflicts or in situations of asymmetric conflict (without violence or warfare). Specifically, we will focus on the institutional design (democratization and democracy), power-sharing incentives and human development. 
The first analytical perspective focuses on the politics of institutional choice in conflict-torn societies. It takes a particular look at "democracy designs" defined by transitions to democracy, especially in cases of decentralization. Although there has been much written on the subject, we have chosen to concentrate on the work of Bastian and Luckham 2003, because they offer a balanced outlook on the design of democracy and democratization. They argue that far from considering that the process is a "general panacea, an adjunct of capitalism or device for engineering solutions to political and social problems, including conflict (...) we regard democracy as a value in its own right ... The emphasis is placed upon how democratic institutions can be reformed to ensure they deliver democratic governance" (Bastian and Luckham, 2003: 1-2). In short, they pose the question, can democracy be designed? The perspective is very interesting for us because, as the authors show, democratic institutions and elected governments may or may not open spaces for democratic politics; they may or not may facilitate the managements of conflicts. "Furthermore, the institutional devices selected by constitution makers seldom function quite in the way intended: a case in point is how an electoral system designed to foster inter-ethnic accommodation had the precisely opposite effect, in Fiji" (Bastian and Luckham, 2003: 3).

These authors conduct their research through six case studies: South Africa, Uganda, Sri Lanka, Bosnia and Herzegovina, Ghana and Fiji. The first four are similar in the fact that they have just suffered from a major armed conflict or are still involved in one. In Bosnia and Herzegovina, peace was imposed from the outside and the result was a very nascent and insufficient form of democracy. In Sri Lanka, political negotiations and military operations against insurgents have not yet finished, nor were they resolved in the year this study was completed. The other two, Fiji and Ghana, which display situations in which there is a general lack of democracy, and military rule and episodic violence are prevalent, but there is not a major armed conflict present.

The authors analyze the cases with a common methodology, having placed them in their respective historical contexts. They then carry out their evaluation at three levels:

- They question how broad principles of democratic governance, as well the desire to prevent conflict, were translated into specific institutional choices in particular national contexts, and other such questions are addressed;

- They offer an analysis of the structure of new or redesigned democratic institutions and their actual operation, including an evaluation of power-sharing arrangements and incentives; and

- They assess the impact of democratic reforms, in areas such as the reduction or the elimination of identity or ethno-political conflicts, the promotion of participation and the respect for minority rights (Bastian and Luckham, 2003:4).

The richness of the whole study -the simultaneous analysis of two cases, Sri Lanka and Fiji, regarding the reinvention of democratic institutions, which was done to 
resolve or prevent violent conflict, four transitions or attempted transitions to democracy - makes it very difficult to summarize the findings.

We would like to address, however, four specific allegations. First, there is no generic answer to the question of whether democracy can be designed? If there was, it would be negative: democratic constitutions do not guarantee democracy, even if well formulated, it cannot guarantee the non-violent resolution of conflicts. This is even more true for countries like Sri Lanka or Fiji, for example, which have a long and problematic history of "constitutional experiment in multi-ethnic societies" (Bastian and Luckham, 2003: 304). Second, despite this statement, "there is sometimes no serious alternative to designing or redesigning democratic institutions". Often the obstacle, the reason because they do not resolve conflicts, is that the existing designs do not address the root causes of reducing inequality and asymmetry, or because the basic structures of the state have collapsed, as in Bosnia-Herzegovina (or in Uganda before 1986 ). "The real issue is how it can be reinvented, by whom and with what prospect (however meagre) of success" (Bastian and Luckham, 2003: 305).

Third, there are many solutions to the diverse problems of each case. There is never a single option; institutional choices can be made in a great variety of ways "(Bastian and Luckham, 2003: 305). Fourth, for several reasons and in many ways, context and history are key factors and will be essential to the success, to bringing about lasting peace. In short, the bringing about of democracy does not occur in an economic or political vacuum. The implementation and design of democracy is often restricted by that who manages it. In other words, the shape of the reforms almost always displays features which can be explained by who the designer was: the designer works usually pro domo sua.

The last point that we would like to address relates directly the theme of our study. The view of the authors is clear: "institutional reform for conflict resolution is necessarily an open-ended process." In their opinion, a) the strategies and procedures for power-sharing and decentralize in order to prevent violence are varied and the results are very different in each case; b) the success or failure depends in part on the context and the coherence between different policies and actions, and c) ·decentralization, in all conflict-torn societies, is not a panacea, and must be tailored to the specific requirements of peace building in the country's particular nation context (Bastian and Luckham, 2003: 310-11).

Let us now shift our analysis to the second standpoint, which corresponds to the approach we have called, "peace as governance, power-sharing arrangements, with a focus on the incentives for inclusion, and participation, which is being offered to armed groups in contemporary peace negotiations. In other words, we looked for studies which concentrated on 'Peacemaking and Peacebuilding' strategies; we would like to specifically address the work of Chandra Lekha Sriram, (Sriram, 2008), for her work offers in-depth field research in three very different cases, Colombia, Sudan and Sri Lanka. In all three cases the armed groups were offered inclusion within the 
structures of power and government. The study also has two additional features that make it especially interesting: a) it offers a critical perspective on the foundations of proposals of peace as governance, the "liberal peacebuilding consensus", and b) from a broadened and more applicable view, she conceptualizes power-sharing as an incentive which relies on the explicit institutionalization of the state and on the use of state institutions. (Sriram, 2008: 2-5). In short, she states that governance incentives also include non-traditional incentives, such as resource-sharing, inclusion into state or regional security structures, territorial autonomy, including several forms of decentralized governance.

Sriram questions whether armed groups should be included in the post-war settlement and power-sharing arrangements, and she formulates her response via an in-depth exploration into the case studies listed above. Specifically, her research involves a critical examination of one of the most common contemporary strategies of peacemaking and peacebuilding, which is that of power-sharing. Sriram's analyzes the promises and the limits of governance incentives, incentives which, according to the liberal peacebuilding consensus, encourage armed groups to negotiate and implement peace agreements.

Her final thesis, remaining consistent with other such investigations, concludes that power-sharing and similar incentives can often reify existing cleavages within societies, increasing rather than decreasing the risk of violent conflict. (Sriram, 2008: 1-6). Power-sharing may end up importing or embedding social divisions, making chronic conflicts more likely, because the new institutions of governance may end up being dysfunctional or too weak to manage emerging conflicts. An example, in the words of Sriram, is the creation of new conflicts, or the stoking of existing conflicts, "where power-sharing excludes significant parties or interests: some Muslims in Sri Lanka, persistently excluded from the formal negotiating process, have become increasingly radicalized, and may see violence as the only route to staking a claim in any future negotiations" (Sriram, 2008: 189).

Finally, in terms of constructive criticism, Sriram defends the need for more nuanced governance incentives (which are outlined below) to offset the risks arising from the "liberal peacebuilding consensus and the a prioris from traditional proposals. Specifically, she proposed that the incentives offered to armed militias to engage in peace negotiations, agreements and to engage in implementation should be explored, during the proposal, negotiation and implementation phase in four dimensions. The first should observe the direct involvement of armed groups in future political processes, through positions in government and through the creation of political parties, etc. The second will evaluate the inclusion of former combatants into the security forces which, typically, have been reformed (in the case of Central America they are known as Policía Nacional Civil). This incentive solves two problems, the more obvious is that it provides employment for those who will become demobilized in the future, and the less obvious is that it offers former militia a position within the state 
apparatus. The third explored is resource-sharing, an incentive that usually takes two forms, offering an armed group direct economic benefits, or giving them a role in the governance of resources (Sriram, 2008: 182). Four and lastly, the incentive of territorial autonomy should be observed, which includes the size and shape of a future region and its government, as well as a presented opportunity for referendum on independence. This incentive offers the armed group the future opportunity to either govern directly, or to have direct access to the government in a specific area, through federal or other arrangements made within a larger state (Sriram, 2008: 182).

Each of the four types of incentives carries with it its own strengths and weaknesses, challenges for negotiation and for implementation. It furthermore, remains crucial that several recommendations to improve the outcomes which are made available to for mediators and donors, in order "to avoid the risk that governance incentives may replicate existing patterns of social dominance, with elites (weather ethnic, caste, class, or other dominant groups) manipulating governance arrangement to maintain dominance" (Sriram, 2008: 190). In short, there is a risk that direct powersharing and similar incentives can often reify existing cleavage in societies. It therefore becomes vital that attention is paid to the root and structural causes, because the exclusive focus on the triggers or accelerators can complicate things in the medium or long term. As De Gaulle would say, this would be another case in point that any political solution begets a new problem.

The third perspective in the literature will be covered more briefly. It is an analysis from 'human development and the economy'. We have selected a major study on the relationship between globalization, self-determination and violent conflict: how global factors have affected violent conflicts and movement for self-determination, and, particularly, the international policy response to self-determinations and violent conflict. We now turn to the works of Valpy FitzGerald, Frances Stewart and Rajesh Venugopal (FitzGerald, Stewart and Venugopal, 2006). In their case studies on Congo, Somalia, Burma, Algeria and Sri Lanka, they consider the role of global actors (international organizations, for example), who are seeking to devise working alternatives. A large part of the proposals made by these actors, such as decentralized governance, intend to "help contain and channel the conflicts over self-determination toward less violent means, and reduce the incidence of violence on the poor and the vulnerable (...but this potential will require...) major changes in international institutions, particularly a more central role for the United Nations as the only representative global institution" (FitzGerald, Stewart and Venugopal, 2006: 17).

This theoretical and conceptual work goes far beyond the usual analysis of "greed and grievance" as main causes of war and violence. The guidelines outlined here for conflict prevention and decentralized governance emphasize the importance, albeit unusual, policy coherence, particularly the coherence with respect to bilateral and multilateral policies of donors in the North and in the South.

These authors show that there is room to build an alternative policy towards mo- 
vements of self-determination, by changing the behavior of the 'global drivers'. They specifically point to the influence of the two major "global drivers: the disaggregated and informal forces of economic and cultural globalization, on the one hand; and, secondly, the conscious policy responses to the "disorder" inherent in the global system, in the areas of, finance, global norms, international law. In addition, we are reminded that it is essential that global institutions are reformed, if indeed durable solutions are to be developed. We must be radical, that is, go to the roots. In his own words: "a first step is to recognize that people have legitimate reasons for selfdetermination and minorities need to have room to manage their lives and not be crushed by majorities (...). The second step is provide international support, which may occasionally include military intervention in order to make this principle effective" (FitzGerald, Stewart and Venugopal, 2006: 257)

In short, these three views or point of views, which only partially and indirectly address the relationship between decentralized governance and conflict prevention, remind us that the success-even the ability to avoid collateral damage or the capacity to prevent aggravating things further in the medium and long term - depends on contextual factors, management opportunities, and above all it relies on incorporating all potential causes (structural, intermediate and triggers) to the proposals and policies of reform and peaceful change.

In sum, the goal for conflict prevention is to generate and strengthen the internalization of the three preventors, mainly oriented to the intermediate and trigger causes, but also the preventors for the structural causes.

\subsection{THE MESO PERSPECTIVE: PROS AND CONS OF DECENTRALIZED GOVERNANCE IN CONFLICT PREVENTION}

So far we have addressed the literature situated in three macro perspectives only indirectly focalized on decentralized governance and conflict prevention. We have evaluated the role of development and the transition to democracy or institutional design in bringing about peaceful governance in various countries of the South. Essentially, the prevailing approach thus far has been one focused in deep structural and underlying causes and their corresponding preventors. In coherence, the policies and proposal addressed to structural and intermediate causes are not focused on the direct relation between decentralized governance and conflict prevention.

Let us now turn to what has been said in articles and in papers on the theoretical and/or actual direct relationship between decentralized governance and conflict prevention in different cases, in varying contexts. First we will address some general issues like the role of normal politics as violence preventor and conflict management tool. After, we will then focus on the specific pros and cons of the relationship between decentralized governance and prevention.

We have classified and ordered the literature, the theses of different books and 
papers, in function of our view about the root causes of violent conflict. In line with parts 1 and 2 of this thesis, we have decided to sort the views of the literature in relation to their relevance to our thesis topic. We will therefore, concentrate our analysis here on the root causes and structural or long -term preventors of the intermediate causes, or accelerators, and finally of the triggers.

Before, however, we would like to address the politics and respective policies that, by definition, attempt to prevent violent behaviour in conflicts, and those that seek to manage a large number of preferences, interests and needs, which exist in every society. The politics must always, in contexts where resources are limited and there exists tension over how they should be distributed, seek mechanisms to manage requests and interests, to allocate preferences, control tensions and conflicts, and of course make decisions. In short, conflict prevention and conflict management are always present in normal, everyday politics.

More specifically, and entering the subject at hand, Brancati, for example, notes that "decentralization is a useful mechanism in reducing both ethnic conflict and secessionism" (Brancati, 2006), a relatively common thesis. But what makes for a more interesting endeavour, is identifying the positive effects of decentralized governance on the prevention of conflicts and evaluating how these impacts are realized in the real world. We are going to directly address this task by observing the significant and lasting influence that decentralization maintains in conflict prevention. To approach this undertaking we are going to put forward the following hypothesis: the positive or negative impact of decentralized governance is a function of its capacity to directly alter the causes of conflict, whether structural, accelerators or triggers- through the generation of incentives, which can act as war preventors within the framework of democratic institutions.

It should be noted, however, that the task of assessing and measuring is a difficult one. There are serious complications in quantitatively and qualitatively evaluating the impacts of decentralization on conflict prevention, particularly in the mediumand long-term, as shown in the next box.

\section{BOX 12: CHALLENGES TO MEASURE THE IMPACT OF DECENTRALIZATION}

A small disclaimer must be made in relation to the difficulties one encounters in measuring the impacts of decentralization on conflict prevention before one proceeds. Despite the large number of studies on this phenomenon, many experts do not dare to specifically assess the impact of decentralized governance on the prevention of violent conflict (Rodden, 2004).

The difficulty is twofold: the first complication lies in isolating and observing the impact of decentralization policies in one particular area (because it has effects in 
many fields at once; and secondly, exists the difficulty of obtaining comparable data between different territories However, if despite these obstacles, conclusions can be drawn concerning the relationship between the two phenomena, although it may be general, it does allow for the benefit of identifying the risks and advantages of decentralization processes.

Like many experts in the field, the academic literature on decentralized governance argues that when it is applied in the proper context, it can be an important tool for conflict prevention, because it may help defuse some of the causes that contribute to violent behaviors.

Let's now turn to an analysis of plausible and credible impacts, both positive and negative, of decentralized governance on the structural causes, intermediate or accelerators and, finally, triggers of violent conflict.

\section{THE IMPACT ON STRUCTURAL CAUSES}

The literature on this matter agrees that the potential impact of decentralized governance on the structural causes of conflict is limited, at least in the short-and mediumterm. This can be attributed to the fact that it is very difficult to influence the causes which we have labeled "necessary and structural". The impact of decentralized governance depends on its combined action with other policies, such as development and development cooperation, distribution and redistribution policies, the political system and political parties system, or the relationship between government and civil society. In short, the coherence between policies and the whole synergy and harmony is more important that the only impact of one of them, as decentralization.

We are still able to highlight certain examples, however, where decentralization does have a positive impact on structural causes. The first area in which decentralized rule can reduce the structural causes of conflict is in the economy and in particular, in the allocation and distribution of resources. As has been previously noted, there are now fewer major armed conflicts, new conflicts are mostly intra-state. In most cases these conflict have a political dimension, but very often they also involve an economic dynamic. Moreover, a large part of these conflicts are located in the Global South or in states going through political or economic transition, whereby inequality and exclusion are common throughout. Poverty and social exclusion are indeed different phenomena: Sub-Saharan Africa is the most impoverished area on the planet, but Latin America is the region with highest levels of social inequality in the world. Both social wrongs, however, generate feelings of grievance and obvious relative deprivation, and often become the source of potential conflict, and potentially a causal factor for the transition to decentralized rule. Naturally, one cannot ignore the political motivations that commonly act as catalysts for movements towards decentralization, 
but it seems that economic inequalities and asymmetries, have gained weight in the discourse on decentralization. As shown by Rodriguez-Pose, "the political rationale for devolution across the globe has also evolved, and shifting from emphasis on cultural, ethnic, linguistic, or religious factors (...) to one of achieving economic and social change" (Rodriguez - Pose, 2003).

Once again, however, there is also reasonable doubt regarding the positive impact of decentralization on national economies and distribution of wealth, and, consistently, differences between the experts. Siegle and O'Mahony indicate that "in fact, this analysis shows that relatively higher levels of sub national expenditure and employment as well as authentic politics decentralization are linked to a lower probability of ethnic conflict" (Siegle and O'Mahony, 2006). While others affirm that "despite the often proclaimed benefits of decentralization for enhanced service delivery, efficiency, convergence and growth, the evidence is at best inconclusive" (Brosio and Ahmad, 2008).

In other words, the "economic dividend," by using an analogy associated with the "peace dividend" which was fashionable in the early years of the Cold War, evaluates decentralized governance founded on the idea of proximity. Having the government nearer to its citizens insinuated better governance. But, 'proximity politics' is not enough. Consequently, fulfilling the basic needs of the population is ultimately crucial to reducing, or at least disabling potential causes for conflict or an escalation towards violence. The rationale here is clear and convincing: we must assume that some public services will be better provided and will be more effective if they are managed by sub-state governments, facilitating a better allocation of resources and satisfaction of preferences and needs. If these public services do in fact maintain a fundamental role in improving the living conditions of citizens, as with education and health, it can be reasonably expected that in the medium and longer term these actions will help reduce the structural causes that lead to the outbreak of conflicts. An example of the potential economic benefits of decentralization is found, in the case already mentioned through the outward decentralization sponsored by the international organizations, particularly through international financial institutions (IFIs).

But, there are also potential negative effects that decentralized governance can impose on the structural causes of conflict. Some experts in the field warn that decentralization can "freeze" conflicts, thus preventing the normal development of social relationships. Consequently, if processes of decentralization or decentralized governance lead to the crystallization of ethnic divisions, this may help maintain or perpetuate the structural causes of conflict (Monteux, 2008), leading to further asymmetry, which can ultimately act as a cause to trigger conflict. To take a well known example: the current situation in Bosnia and Herzegovina is of particular concern to the extent that the situations of the independent regions of the Bosniak/Croat Federation of Bosnia and Herzegovina and the Bosnian Serb-led Republika Srpska maintain, if not aggravate-ethnic dividing lines. 
In relation to the intermediate causes of conflict, there is an important area where decentralized governance may have a positive effect and that is on the distribution of power. The distribution of power, even if it is not entirely balanced, acts as a warpreventor through reducing the possibility of accelerators or intermediate causes for conflict. When the distribution of power is more equitable and power-sharing arrangement are genuine and profound, whereby the parties and/ or groups (ethnic, political, social, etc.) actually enjoy influence over governmental decisions, the less likely the emergence of a violent conflict is going to be. In this regard, one of the key capabilities of decentralization, as an element of conflict prevention, is its capacity to include new political groups through the distribution of power (Schou and Haug, 2005). We have also summarized above the work of Sriram to address this point.

Decentralization processes may allow for the participation of excluded minority groups at the national level. With decentralization various social groups have the opportunity to form political parties who, despite being in the minority, have a political space that allows them to defend their interests and make their preferences public. Recall that partaking in electoral processes is one of the key incentives offered in peace processes and negotiations. In this manner decentralization can assuage the yearning of secessionist groups to separate, because they are now represented and recognized politically, subsequently, minimizing the risk of violent dispute. This inclusion can, therefore, defuse what could become potential or permissive causes for violent conflict in the future. The participation of all actors in politics helps transform conflicts by facilitating open discussions channeled through existing institutions. A paradigmatic example in this regard is the Catalan case and Spanish case, one of the case-study of the Forum.

In the same vein, running parallel to the inclusion of new groups, a second incentive is present, which is the rise of democratic legitimacy via the recognition of minorities and the deepening of the distribution of power. Incorporating new groups and ensuring the participation of minorities through new spaces for political representation reinforces democracy. Such potential benefits of decentralized governance can be developed to reduce the intermediate causes of violent conflict, the accelerators. Many experts point out that decentralization can serve as a mechanism that pulls sub-national groups to enter into negotiation processes with the central state and other levels of government. If there is a more equitable distribution of power, which incorporates a larger number of actors in decision-making processes the legitimacy of public institutions is enhanced (Sisk, 2001). There are several examples of this strengthening of the state through decentralization on the African continent. Power-sharing and representation arrangements, institutionalized through decentralization, have served to attract minorities and regions threatening to secede, such as in the case of Nigeria. Decentralized rule also works to strengthen the unitary 
state after open conflict, as in South Africa after the apartheid. In fact, decentralized governance, in these cases, appears to have solved a key element of what the United States literature about conflict resolution has called "intractable conflicts", or protracted social conflicts (Edward Azar).

Also in relation to power-sharing, and as a corollary of the above, another potential positive impact on the intermediate causes of conflict is the promotion of stability. The distribution of power among a larger number of levels and actors, as is common in the multilevel governments common in western democracies, appears to reduce problems and disruption in decision making and to increase the space for potential vetoes. This increased capacity for refutation and dissidence management offered by a decentralized system limits the ability for abrupt changes and strengthen the negotiation processes through governance incentives. The number of stable decentralized countries is high, and a perfect case in point is the United States, which is a huge, stable country with 300 million inhabitants (a large number of which are minorities), who have had a constitution detailing decentralization dating back to no less than 1787 .

There remains a third area where decentralization potentially, positively impacts the intermediate causes for war and violence through power-sharing: to increase transparency and accountability. A greater number of governing levels and the presence of more actors (governmental and non-governmental, as the civil society) promote government control, with the consequence of increasing transparency. From the point of view of institutional choice, one can argue that the vertical division of powers (decentralized governance) can have effects similar to those of horizontal division, whereby the different powers and the performance of their functions is monitored. Here we can talk about checks and balances as an essential component of genuine democracy

There remains one final area that we will discuss here; which although minor must be taken into account: the positive impact that decentralized governance has on administrative efficiency. Administrative efficiency can also be regarded as a war preventor to the extent that it functions eroding the underlying causes for violence because the system works, the government can provide a better and a more costefficient service, and, also, closer to the citizen. It is not easy to deduce what is the optimum scale for the provision of each service, but it is intuitively easy to understand that planning for national defence is not the same as that for urban transport planning. It is recommended that each level of government should have jurisdiction over the areas where its control and production can be more efficient (the so-called principle of subsidiarity).

However, not all of decentralization's impacts on intermediate causal factors are positive, so far seeming paradisiacal. Despite the potential positive outcomes listed above, decentralized governance can also lead to some potentially negative effects on the nature of the conflict, its evolution and on relationships and interests in each 
phase. Many authors warn us that the positive effects of decentralized governance (in conflict prevention or in other areas) are not guaranteed. The results may even be perverse. One can therefore, not ignore the fact that the implementation of decentralizing measures, such as those already discussed, may have unwanted effects, feeding the intermediate causes of conflict.

Some social movements, armed or not, can use decentralization as a step to secession or as a formula to achieve independence. Their inclusion in governance through decentralization may strengthen the legitimacy of the existing divisions and causing further instability. This slippery slope, of entering into agreements on decentralized governance with groups seeking independence, is possibly the main fears of central governments unwilling or reluctant to implement decentralization processes. The establishment of decentralized institutions and processes may be associated with an increased permissiveness towards the demands of minorities, creating an environment prone to independence.

The clearest examples of this occurring are found in the Soviet bloc after the fall of the Berlin Wall; the case of the dissolution of Czechoslovakia is illustrative of the way this dismantling process may unfold. Even in cases where decentralization is more consolidated, as it is in Spain, there are increasing critical voices regarding the current amount of decentralization and the level of independence, and the emergence of new parties, who are conversely, strongly opposed to decentralization illustrate the existence of tensions associated with the relative power of subnational governments.

Among the possible negative causes of decentralized governance at the intermediate level, the proliferation of regional parties must also be evaluated (Brancati, 2006). Decentralization politics tends to reinforce minority identities, creating or strengthen ethnic-politic cleavages, and may result in one of the necessary or structural causes of violent-prone conflict. Therefore, while the direct effect of decentralization may be to reduce conflict-potential and limit secessionist wills, it may also indirectly have a negative effect by allowing the emergence of regional parties who are prepared to pursue minority goals, leading conversely, to an increase in secessionist demands. Also, if within the framework of regional parliaments, secessionist minority groups achieve significant levels of power, one of the potential pitfalls of decentralization is that these groups, having the capacity to legislate, may do so in manner which goes against the interests of a part of citizenship. The current situation in Belgium (which was mentioned by Brancati as a successful), with strong tensions between Flemish and francophone parties, could illustrate this aspect.

A final negative consequence is found in the administrative dimension, which can be described as a lack of coordination between levels of government. The shared responsibility over public goods can end up with the emergence of free riders. This may occurs if a certain level of government tries to benefit from the lack of coordination and of central control to maximize its profits without contributing to overall creation of wealth. A good example of this lack of coordination could be Bosni-Herzegovina; 
following the results of the decentralization round table at the Balkans Regional Seminar organized by the Mediterranean Commission of United Cities and Local Governments, Bosnia-Herzegovina is a clear case of lack of coordination mechanisms between government levels.

\section{THE IMPACT ON IMMEDIATE CAUSES OR TRIGGERS}

We come now to the immediate causes of conflict, the "drop that fills the cup" and provokes the occurrence of violence. The decentralized governance can help prevent or reduce violent conflict, in that it potentially has the capacity to disable the immediate causes or triggers of war or violence. What gains importance here is the improvement in the allocation of preferences in a more egalitarian fashion, essentially matching preferences with public policies, which may in turn have a preventing impact on violent behaviour? In this sense decentralization can act as an impediment of the triggers of an outbreak of violence. The argument posited here is that local and regional governments have more information on the necessities and preferences of citizens, so they can properly prioritize policies and appropriately implement them. If the various levels of government have more information on citizenship and are able to detect more quickly the needs of the population, then it is concluded that there is less probability of a conflict breaking out in response to minorities feeling that their demands are not being taken into account. This proper allocation and channelling of society's demands eases the triggers of conflict.

Along the same lines, we find the stability conferred by the existence of an articulated institutional complex of procedures and norms as a potential war preventor, as a diffuser of conflict triggers. By acting as a network, a stable institutional complex can inhibit conductors of violence. The creation of a network of links based on governance incentives affects the spread of conflict, since it distributes responsibilities to the players involved in the negotiation process and limits the potential gains in case of conflict. In a context in which each level has a number of responsibilities, and therefore areas of expertise, the groups will need to learn to negotiate. The creation of structures to make decisions and their implement through the formation of a network provides a series of links (both administrative and political), which promote collaboration. This structural network functions as a conflict preventor, disabling possible triggers and hindering the emergence of violent conflict. The case of India illustrates how the existence of a political, economic and social complex makes the emergence of conflict difficult (Sinha, 2005).

The last group of potential positive effects of decentralized governance with respect to diffusing conflict triggers is found in the flexibility and innovation of noncentral governmental institutions, particularly in the short term. The governing proximity between new levels of government and citizens allows for the tailoring and innovation of action (especially action which is taken in response to the potential out- 
break of a conflict), which the central state is not capable of doing. Specifically, subnational governments are more directly responsible for the welfare of their identified population; this may lead them to try to improve their situation through the implementation of more innovative policies (Rodriguez-Pose, 2005). Furthermore, competition among municipalities and regions promotes growth and innovation, because the small scale makes it easier to find successful solutions to problems that could lead to the outbreak of a violent conflict. It is mainly in the political management of public spending on services and in the collection of taxes where innovation can be seen more often. It should be noted that the theme of innovation is important not only in economic terms, since subnational governments may also function as laboratories in the political arena; it is easier to experiment with and implement innovative policies at a smaller-scale, then at higher levels. An illustrative example is the case of the Brazilian city of Porto Alegre with the implementation of the innovative participatory budgeting formulas, which was done for many years (but is no longer the case).

Unfortunately, decentralized governance can also act as trigger for a new conflict, directly or indirectly. From the standpoint of the economy and the distribution of wealth, decentralization processes may have unwanted effects. Although corruption is a real problem at all levels of government, in many countries, the processes of implementation of decentralized governance can result in the emergence of local or regional tyrannies, which seek to monopolize the political game. This usually takes place for economic reasons, which consequently, has an adverse affect on the proper functioning of the various levels of government, and may end up triggering conflicts.

In the same line of argument, we find another risk cited by experts in the field and that is the furthering of inequality. This is especially acute in cases where there is great disparity in the distribution of resources. In cases like this you run into the risk of creating conditions which are conducive to accelerating the intermediate causes of conflict and, finally, the occurrence of violence. An example is the will of the Bolivian department of Santa Cruz for more powers, especially in the managing of their own natural resources, and further events.

The following box summarizes the ideas just presented on the potential positive and negative impacts of the decentralized governance on the three types of causal factors of violent conflict. 


\section{BOX 13. DECENTRALIZED GOVERNANCE AND CONFLICT PREVENTION: IMPACTS ON CAUSES}

\begin{tabular}{|c|c|c|}
\hline & Positive Impact & Negative Impact \\
\hline $\begin{array}{l}\text { Structural } \\
\text { Causes }\end{array}$ & $\begin{array}{l}\text { - Satisfying basic } \\
\text { needs }\end{array}$ & $\begin{array}{l}\text { - Crystallization of } \\
\text { ethnic divides }\end{array}$ \\
\hline $\begin{array}{l}\text { Accelerators } \\
\text { or } \\
\text { Intermediate } \\
\text { causes }\end{array}$ & $\begin{array}{l}\text { - Inclusion of new } \\
\text { political groups } \\
\text { - Increase in legitima- } \\
\text { cy in democracy } \\
\text { - Increase of stability } \\
\text { - Increased } \\
\text { transparency } \\
\text { - Efficient administra- } \\
\text { tive capacities }\end{array}$ & $\begin{array}{l}\text { - Stepping stone to } \\
\text { secession } \\
\text { - Proliferation of } \\
\text { regional parties } \\
\text { - Lack or coordination } \\
\text { between the levels }\end{array}$ \\
\hline $\begin{array}{l}\text { Triggers or } \\
\text { intermediate } \\
\text { causes }\end{array}$ & $\begin{array}{l}\text { - Ability to match } \\
\text { or fulfill and imple- } \\
\text { ment preferences } \\
\text { - Existence of an } \\
\text { articulated institu- } \\
\text { tional complex } \\
\text { - Flexibility and } \\
\text { innovation }\end{array}$ & $\begin{array}{l}\text { - Local or regional } \\
\text { tyrannies that } \\
\text { monopolize the } \\
\text { political game } \\
\text { - Furthering of } \\
\text { inequalities }\end{array}$ \\
\hline
\end{tabular}




\section{CONCLUSIONS AND FURTHER \\ RESEARCH}

The analysis proposed by this paper merges two conceptual and practical proposals that, separately, have played an important role in the debates on the peacebuilding and conflict transformation field during the last 15 years, in the academic world as well as in the praxis of international organizations, non-central governments (cities, regions) and NGOs. Those concepts are conflict prevention and decentralization and decentralized governance.

Even though it is widely accepted that decentralized governance contributes to the prevention of violent conflict during different phases (from the very outset until the outbreak of the conflict, and even after a peace agreement), the veracity and universality of the link between decentralized governance and conflict prevention has not been studied in depth. This is exactly what this paper attempts to tackle.

The paper starts from two assumptions. First, the commitment with the initial axiom of peace research and conflict transformation: the causes of war/violence can be known and, consequently, it is possible to propose actions to avoid them (preventors), even in contexts of emergent conflicts. Secondly, and a commitment of the ICIP, it is deemed necessary to create and Observatory on Decentralized Governance and Conflict Prevention. Thus an additional task is to establish operational definitions and complete a critical study of the existent literature.

After stating the initials assumptions and objectives of the paper, the second section has been devoted to the current context; the confluence of new types of armed conflicts (intra-state, with a strong political dimension, including those conflicts where there is social unrest and demands of power and resources distribution), the process of urbanization and the spreading of decentralization processes.

The new demands for security based on people (human security), and new threats and types of violence (drug trafficking, juvenile violence, etc.) generate challenges for societies and states. Principles of sovereignty and non-interference continue to be basic in international relations, but they have been perforated and challenged from several angles such as from the emergence of new actors, the confluence of peace agendas, security and development, the appearance of new ethical and political demands (like the responsibility to protect during humanitarian crises that, even though they are internal, might end up provoking major armed conflicts).

The third section of the paper has been devoted to the creation of an analytical framework, paying particular attention to the causes of war and the role of violence preventors. In this section, conflict prevention is defined as every mean that allows for the reduction of violence and limits the outbreak of armed conflict; it aims at generating a mechanism that transforms conflict and eliminates or reduces the causes 
that sustain it. Theses causes can be structural, intermediate as well as trigger causes. Provided that all the causes should be faced, conflict prevention is focused basically on the short- and medium-term causes (triggers and intermediate). On the other hand, peacebuilding, development and cooperation are focus on in the long-term as structural causes.

It has been shown that there are practices and instruments, the so-called preventors, which allow for the extension of peaceful change vis-à-vis violent change. Three elements are essential to manage (inevitable) social conflicts and to promote peaceful change: first, democratization and institutional design, which focus on the institutional policies and procedures to transform conflicts, particularly in decentralized governance; secondly, structural changes that promote development and human security, given the fact that they reduce imbalances and social exclusion, improves the welfare of human beings, and help to establish less conflict-prone societies; and thirdly, good governance, inclusion incentives, and power-sharing incentives (political, and also in security structures and resources sharing).

Sections four and five have been devoted to defining conflict prevention and decentralized governance, as well as analyzing the impacts of the latter on the former. In this process the complexity of assessing these impacts is discussed in the light of the heterogeneity of experiences. The difficulty in identifying causality or the absence of long-term comparable data is also addressed. Thus, the paper focuses on evaluating the effects of decentralization in concrete cases in the short- and medium-term. This is done from both a macro and a meso perspectives (engaging conflict prevention and decentralized governance, as well as taking decentralization as a direct factor of violence reduction).

This approach has allowed us to extract several conclusions:

\section{A. FROM A GENERAL AND MACRO PERSPECTIVE}

The strategies of institutional design, for example in the field of decentralization, democratization and power-sharing, are diverse; there is never a single option. Institutional choices can be made in a great variety of ways and, thus, there is no universal recipe.

1. The success or failure of this approach will depend, not only of the strategies used, but also contextual factors, history and, in particular, cultural factors. In general, strategies that have taken into account the cultural and social features of the societies tend to work better, leading us to state that context-sensitive approaches have a higher probability of success.

2. Power-sharing incentives are sometimes too traditional; very often the success of these initiatives depends on the ability to offer more nuanced governance incentives. 
3. In the case of strategies dealing with development processes, the role of 'global drivers' should be taken into account, particularly given the need to reform global institutions.

4. When fostering democratization, decentralization, governance incentives, and human development, it should be acknowledged that reaching these strategic goals could imply the appearance of collateral problems and even contradictions; very often negative effects will arise in the medium- and long-term.

5. More generally, it is important to acknowledge the rights of minority groups, consequently, accepting the right of people to decide the shape of their own governments within the limits established by international legality. Again, we run into the debate about the limits of sovereignty, a very relevant issue in the post-Cold War world.

\section{B. FROM A MESO AND IMPACT-ASSESSMENT PERSPECTIVE}

6. The impacts of decentralized governance can be detected mainly on the intermediate and immediate causes (triggers). Regarding structural causes, which are key on the long run, a broader analysis must take place given the need to study the coherence of diverse policies, including peacebuilding and development and development cooperation

7. In terms of intermediate causes, decentralized governance can act as a war preventor through the inclusion of new political groups, strengthening democratic legitimacy, and fostering stability and administrative efficiency.

8. Regarding immediate causes, decentralized governance limits the possibility of violent outbreak through the creation of a complex institutional network that reduces the benefits of those thinking on using violence as a means of reaching their goals; at the same time, power-sharing improves the process of matching preferences and provides the state with a higher degree of flexibility innovation potential.

9. However, decentralized governance is not a panacea; its implementation could foster undesired effects or even produce results completely opposed to those it is trying to obtain.

10.In some cases, it is possible that decentralization measures result in serious problems of lack of coordination, the appearance of regional parties willing to legislate against important parts of the citizenry, the unleash of local tyrannies , the growth of economic disparities or the crystallization of ethnic divisions.

In sum, as a general conclusion, a three-fold thesis can be contended:

a. Decentralized governance might have very positive effects in terms of conflict prevention, given its ability to foster the creation of war/violence preventors 
and by reducing (or eliminating) the three types of causes that generate violent behaviors.

b. Provided that decentralized governance focuses on intermediate and immediate causes, coordination and coherence of long-term policies (both internally and internationally) should not be forgotten. Specifically, the coherence between peacebuilding, conflict prevention, development and human security policies remains a key issue to achieve peaceful societies in the long-term.

c. The use of decentralized governance as a war preventor mechanism is not exempt of risks and its success cannot be guarantee because of the existence of unpredictable contextual factors. In other words, the implementation of decentralization processes could entail perverse effects that deepen the causes of conflict instead of contributing to its transformation and resolution.

It remains clear that there is a long road ahead. Once the link between decentralized governance and conflict prevention has been established, further research should continue, analyzing the capacity of decentralized governance as a war preventor. Until now, we know very few things.

As show in box 14, the graph developed by Sasaoka illustrates the need to combine the goals of decentralization that could prevent a conflict situation (social development, establishment of governance, supression of post-conflict antagonism, etc.) with the motivations for decentralization (governance design, public sector reform, elite capture, etc.) provided they are different and often contradictory.

\section{BOX 14: ANALYTICAL FRAMEWORK FOR DECENTRALIZATION AND CONFLICT PREVENTION}

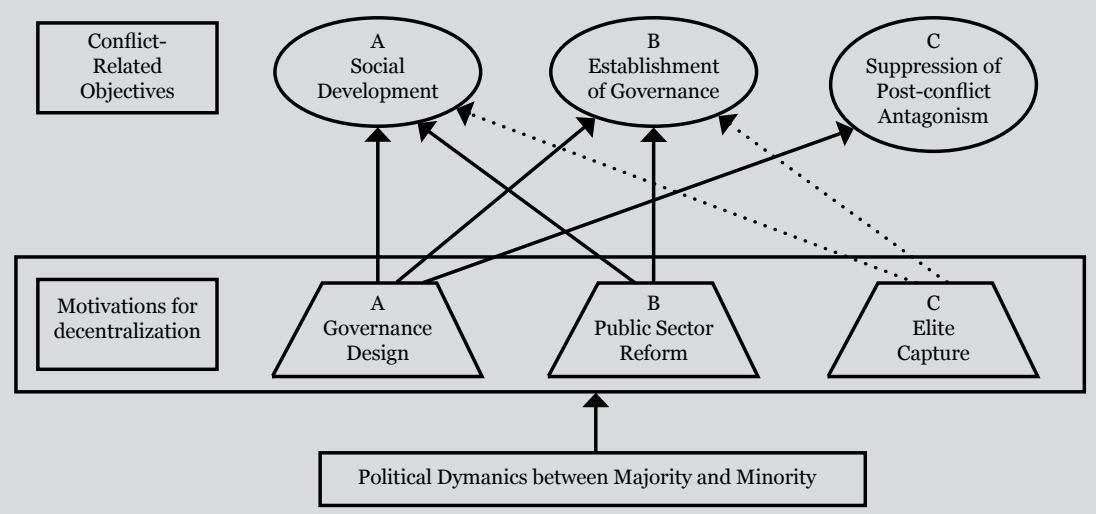

Sourge: Created by Yuichi Sasaoka. Note: Arrows do not connect all motivations and objectives 
To know in each case what type of causal linkage, influences and correlation exist between conflict-related objectives and motivations for decentralization seems like a promising and suggestive task. However, this remains in the to-do list.

Future investigations should develop the analysis presented in this paper through the following initiatives:

- The operationalization of an analytical framework that allows a case-by-case study of Sasaokas's model.

- The identification of the scenarios and conditions which are conducive to the use of decentralized governance as a war preventor.

- The study of the necessary attributes for the correct implementation of decentralized governance in a fashion that impedes the emergence of negative, undesired effects.

- The analysis of control and supervision mechanisms amongst actors, as well as the relation between activities and goals for each potential stakeholder in the decentralization processes.

- In-depth case studies

All of the aforementioned lines of investigation will be tackled, should the ICIP develop an Observatory on Decentralized Governance and Conflict Prevention in 2010. 


\section{BIBLIOGRAPHY}

Ackerman, Alice (2003), "The Idea and Practice of Conflict Prevention”, Journal of Peace Research, vo. 40, $\mathrm{n}^{0}$ 3, pp. 339-347.

Alesina, Alberto/ Spolaore, Enrico (2003), The Size of Nations, MIT Press.

Bastian, Sunil/Luckham,Robin (2003) (eds.), Can Democracy be Designed? The Politics of Institutional Choice in Conflict-Torn Societies, Londres, Zed Books.

Binder, Juergen K. et al. (2007), Towards an EU approach to democratic local governance, decentralisation and territorial development, European Comisión, Background Paper, Bruselas.

Blanchard, Olivier/Schleifer, Andrei (2000), "Federalism with and Without Political Centralization: China versus Russia” NBER Working Paper, Cambridge, Massachusetts, National Bureau of Economic Research.

Boex,Jamie(2001),AnIntroductory OverviewofIntergovernmentalFiscalRelations, training material for a workshop organized by the UN Capital Development Fund, Local Bodies Finance Commission, and Georgia State University.

Boutros Boutros Ghali(1992),Agendafor Peace: Preventive Diplomacy,Peacemaking and Peace-keeping. Report of the Secretary-General, adopted by the Summit Meeting of the Security Council on 31 januari 1992, A/47/277-S/24111, 17 june; New York, United Nations.

Brancati, Dawn (2006), "Decentralization: Fueling the Fire or Dampening the Flames of Ethnic Conflict and Secessionism?" International Organization, 6o, Summer 2006, 651-685.

Brancati, Dawn (2009), Peace by Design. Managing Intrastate Conflict through Decentralization, Oxford U.P.

Brosio, Giorgio/Ehtisham Ahmad (2008), Local Service Provision in Selected OECD Countries: Do Decentralized Operations Work Better?, Working Paper No. 08/67, International Monetary Fund.

Bush, Kenneth (2004), Building Capacity for Peace and Unity. The Role of Local Government in Peacebuilding, Federation of Canadian Municipalities.

Cheema, G. Shabbir/Dennis A. Rondinell (2007) (EDS.) Decentralizing governance: emerging concepts and practices, John F. Kennedy School of Government, Harvard University.

Choudhry, Sujit (2008) (ed.), Constitutional design for divided societies: integration or accommodation?, Oxford University Press.

Ciutats i Governs Locals Units (2008), Primer Informe Global sobre Descentralització i Democràcia Local, Barcelona.

Cornell, Svante E. (2002), "Autonomy as a Source of Conflict: Caucasian Conflicts in Theoretical Perspective”, en World Politics, Vol. 54, No. 2,pp. 245-276.

Diamond, Larry (2004), Why Decentralize Power in A Democracy?, Paper present- 
ed to the Conference on Fiscal and Administrative Decentralization, Baghdad, February 2004.

Fitzgerald, Valpy/Stewart, Francis/Venugopal, Rajesh, Globalization, Violent Conflict and Self-Determination, Houndmills, Palgrave/Macmillan.

Gerring, John/Strom C. Thacker/Carola Moreno (2005), "Centripetal Democratic Governance: A Theory and Global Inquiry”, The American Political Science Review, Vol. 99, No. 4, pp. 567-581.

Grindle, Merilee S. (2007), Going local: decentralization, democratization, and the promise of good governance, Princeton University Press

Harzell, Caroline A,/Matthew Hoddie (2007), Crafting Peace: Power-Sharing Intitutiond and the Negotiated Settlement of Civil Wars, Philadephia, Penn State University Press.

International Crisis Group (2004), Iraq: can local governance save central government?, ICG Middle East Report 33.

Jackson, Paul/Zoe Scout (2007), Local Government in Post-Conflict Environments, Commissioned Paper for the Workshop on Local Government in Post-Conflict Situations, Oslo Governance Centre, United Nations Development Programme, Oslo.

Kauzya, John-Mary (2005), Decentralization: Prospects for Peace, Democracy and Development, DPADM Discussion paper, United Nations Department of Economic and Social Affaire.

Lederach, John Paul (1997), Building Peace: Sutainable Reconciliation in Divided Societies, Washington, United States Institute of Peace.

Luard, Evan (1986), War in International Society, London, I.B. Tauris Ltd.

Lundt, Michael S. (2002), "Preventing Violent Intrastate Conflicts: learning Lesson from Experience", in Van Tongeren, van de Veem \& Verhoeven 2002,pp. 99-119. Lustick, Ian S/Dan Miodownik/RoyJ.Eidelson(2004), "Secessionism in Multicultural States: Does Sharing Power Prevent or Encourage It?" The American Political Science Review, Vol. 98, No. 2, pp. 209-229.

Miall, Hugh (2007), Emergent Conflict and Peaceful Change, Houndmills, Palgrave/ Macmilan.

Musch, ARNE (2008) (ed.), La Diplomacia de las Ciudades; el papel de los goobiernos locales en la prevención de conflictos, la consolidación de la paz y la reconstrucción post-conflicto, VNG, La Haya.

O'Neill, Kathleen (2005), Decentralizing the State: elections, parties, and local power in the Andes, New York, Cambridge University Press.

Pagano, Michael A./Robert Leonardo (2007), The dynamics offederalism in national and supranational political systems;, New York, Palgrave Macmillan.

Prud'home, Remy (2001), "Decentralization Mechanisms," UNCDF Workshop on Decentralization and Local Governance in Africa, Cape Town.

Richmond P. Oliver (2007), The Transformation of Peace, Houndmills, Palgrave/ 
Macmilan.

Rodden, Jonathan (2004), Comparative Federalism and Decentralization: On Meaning and Measurement, en Comparative Politics, Vol. 36, No. 4, pp. 481500.

Rodden, Jonathan/Erik Wibbels (2002), "Beyond the Fiction of Federalism: Macroeconomic Management in Multitiered Systems", World Politics, Vol. 54, No. 4, pp. 494-531.

Rodden, Jonathan (2003), "Reviving Leviathan: Fiscal Federalism and the Growth of Government”, International Organization, Vol. 57, No. 4, pp. 695-729.

Rodríguez-Pose, Andrés/Adala Bwire (2003), The economic (in)efficiency of devolution, working paper, Department of Geography and Environment, London School of Economics.

Rodríguez-Pose, Andrés, y Nicholas Gill (2005), “On the 'economic dividend' of devolution”, Regional Studies, n. 39, pp. 405-420.

Romeo, Leonardo (2002), Local Governance Approach to Social Reintegration and Economic Recovery In Post-Conflict Countries: Towards a Definition and a Rationale, Discussion Paper, United Nations Capital Development Fund.

Sato, Motohiro (2002), "Intergovernmental Transfers, Governance Structure and Fiscal Decentralization,” Japanese Economic Review, 53, pp. 55-76.

Schou, Arild/Haug, Marit (2005), "Decentralization in Conflict and Post-Conflict Situations," Working paper 139, Norwegian Institute for Urban and Regional Research, Oslo.

Siegle, Joseph/O’Mahony, Patrick (2006), “Assessing the Merits of Decentralization as a Conflict Mitigation Strategy,” paper prepared for USAID's Office of Democracy and Governance, Washington.

Sinha, Aseema (2005), "Political Foundations of Market-Enhancing Federalism: Theoretical Lessons from India and China," Comparative Politics, Vol. 37, No. 3, pp. 337-356

Sisk, T. D., ed. (2001), Democracy at the local level: international IDEA's handbook on participation, representation, conflict management and governance, International Institute for Democracy and Electoral Assistance, Stockholm.

Shah, Anwar/Theresa Thompson (2004), Implementing decentralized local governance: a treacherous road with potholes, detours and road closures, Policy Research Working Paper 3353, World Bank.

Sharma, Chanchal Kumar (2005), "Why decentralization? The puzzle of causation", Synthesis, vol. 3 n. 1.

Sharma, Chanchal Kumar (2009), "Emerging dimensions of decentralization debate in the age of glocalization”, Indian Journal of Federal Studies, $n^{0}$ 1, pp 47-65.

Shaw, Greg M/Stephanie L. Reinhart (2001), "Devolution and Confidence in Government", Public Opinion Quarterly, vol. 65 n.3.

Smoke, P. (1999), "Understanding Decentralization in Asia: An Overview of Key 
Issues and. Challenges," Regional Development Dialogue, Vol. 20.

Sriram, Chandra Lekha, Peace as Governance. Power-Sharing, Armed Gorups and Contemporary Peace Negotiations, Houndmills, Palgrave/Macmillan.

Stewart, Francis (2001), Horizontal Inequalities: A Neglected Dimension of Development, Oxford, Cener for Research on Inequality, Human Security and Ethnicity

Stewart, Francis/Meghan O'Sullivan (1998), Democracy, Development and ConflictThree Cases, Oxford, Queen Elizabeth House, Working Paper QEHWPS15.

Tilly, Charles (ed) (1978), From Mobilization fo Revolution, Reading, AddssonWesley,

Tilly, Charles (1990), Coercion, Capital and European States, AD990-1992, Oxford, Blackwell.

Tilly, Charles (2003), The Politics of Collective Violence, Cambridge. Cambridge U.P.

Treisman, Daniel (2007), The architecture of government: rethinking political decentralization, Cambridge, Cambridge U.P.

UN-Habitat (1997) Directrices sobre descentralización, Adopted by de the Executive Board, Nairobi.

Van Tongeren, Paul/Hans van de Veem\& Juliette Verhoeven (2002) (eds), Searching for Peace in Europe and Eurasia: An Overview of Conflict Prevention and Peacebuilding Activities, Boulder, Co, Lynne Rienner.

Van der Pluijm, Rogier (2007), Diplomacy; The Expanding Role of Cities in International Politics, The Hague, Netherlands Institute of International Relations.

VV.AA. (1999), Decentralization: A sampling of definitions, UNDP.

VV.AA. (2008), El paper dels governs locals en la construcció de la pau, Ajuntament i Diputació de Barcelona.

Whitford, Andrew B. (2007), "Decentralized Policy Implementation", Political Research Quarterly, vol. 60, n.1.

Work, Robertson 2005), The Role of Participation and Partnership in Decentralised Governance: A Brief Synthesis of Policy Lessons and Recommendations of Nine Country Case Studies on Service Delivery for the Poor, UNDP New York. 